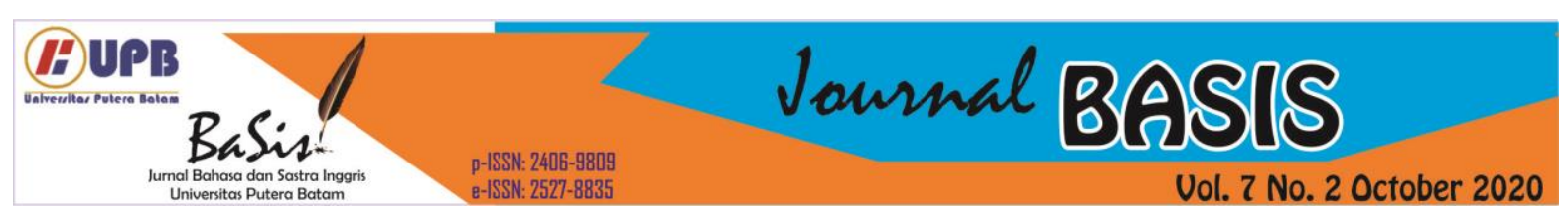

\title{
MEETING ROOMS NAMING IN EAST JAVA GOVERNMENTAL BUILDING: A STUDY OF ANTHROPOLOGICAL LINGUSITICS
}

\author{
Elvana Permataswari \\ Universitas Airlangga, Surabaya, Indonesia \\ e-mail: elvelvana@gmail.com
}

\begin{abstract}
Naming is a specific linguistic act, intimately linked with values, traditions, hopes, fears and events in people's lives. Names reveal the many preferences of their owners (or givers) in terms of real life objects, actions, features and beliefs. Place names provide the most useful geographical reference system in the world. The topic of names is a multidisciplinary field that has occupied the attention of philosophers of language, anthropologists, linguists and ordinary people. In this study, I try to analyze the names of meeting rooms in the East Java Governmental Building. The reason to choose this object is because the East Java Governmental Building is the center of government/ administration in East Java. This study aims to find out the kinds of names applied in the naming of meeting rooms in the East Java Governmental Building and the presuppose reasons behind the name chosen of the East Java Governmental Building. This study is a qualitative study. Based on the classification of the data, they were classified to two groups: the names of governors in East Java and the names of the kings or military chief of great kingdoms in East Java. The meeting rooms in the governmental building of East Java are named after important people in the history of the province. To conclude, the administration named all the meeting rooms, as the most important rooms in the building to welcome guests, using the name of people who have big influence and involvement in the history of East Java so that it has roots to its history.
\end{abstract}

Keywords: naming, institutional, anthropological linguistics

\section{INTRODUCTION}

Naming is a specific linguistic act, intimately linked with values, traditions, hopes, fears and events in people's lives. Names reveal the many preferences of their owners (or givers) in terms of real life objects, actions, features and beliefs (Rosenhouse, 2002). There are many studies in namings, in general it is called as Onomastic. Onomastics originates from the Greek

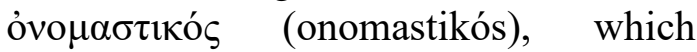
translates to "of or belonging to naming", from ővo $\mu \alpha$ (ónoma) meaning "name".
The study of personal names "anthroponomastics" is an interesting area of research that comes under Onomastics. Onomastics is a branch of semantics. It studies the etymology of proper names (Crystal, 1999). However, the topic of names is a multidisciplinary field that has occupied the attention of philosophers of language, anthropologists, linguists and ordinary people.

Personal names occur in any language and they basically change, develop, and die out, and they have a life cycle similar to that of the other lexical 
items of the language (Rosenhouse, 2002).

Here, the researcher wants to analyze the naming of places that is called toponomastic. Toponymy or toponomastics, the study of place names, is one of the principal branches of onomastics. The word "toponymy" is derived from the Greek words tópos

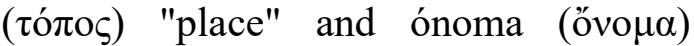
"name". Toponymy is itself a branch of onomastics, the study of names of all kinds. In a more restricted sense, the term 'toponymy' refers to an inventory of toponyms, while the discipline researching such names is referred to as toponomastics.

Place names provide the most useful geographical reference system in the world. The exact application of a toponym, its specific language, its pronunciation, and its origins and meaning are all important facts to be recorded during name surveys. Scholars have found that toponyms provide valuable insight into the historical geography of a particular region. Toponymists are responsible for the active preservation of their region's culture through its toponymy.

The topic of names is a multidisciplinary field that has occupied the attention of philosophers of language, anthropologists, linguists and ordinary people. In this study, I try to analyze the names of meeting rooms in the East Java Governmental Building. The reason to choose this object is because the East Java Governmental Building is the center of government/ administration in East Java. And the existence of the meeting rooms in the building are also very important since they are the places for the governor of East Java to welcome his/her guests. This may have relation to the reasons behind the naming of the meeting rooms there.

\section{LITERATURE REVIEW \\ 2.1.Theory of the Study}

There are two branches under the umbrella of onomastics, anthroponomastics which deals with personal names and toponomastics that deals with the study of the names of places. Lexemes found in anthroponomastics bear witness to the values and ideas of the society concerned, revealing details about people's origins and professions, tradition and fashion, social rank, etc. Anthroponomastic studies are based on the theory that there is a strong interface between a people's language and their cultural practices. It mirrors on how language is used as cultural practices and how language is used as a powerful tool to view and understand the world view of a particular society. One can therefore use language as a microscopic lens to view and understand the social practices and day-to-day activities of a society.

In this study, the focus is toponomastics since this study tries to analyze the meeting rooms naming in the East Java Governmental Building. Toponomastics is the study of place names (toponyms), their origins, meanings, use and typology.

Scholars have found that toponyms provide valuable insight into the historical geography of a particular region. In 1954, F. M. Powicke said of place-name study that it "uses, enriches and tests the discoveries of archaeology and history and the rules of the philologists. Toponymists are responsible for the active preservation of their region's culture through its toponymy.

\subsection{Previous Studies}

Research on naming analysis were found in some studies. One study was conducted by Abdul Wahed Qasem Ghaleb Al-Zumor (2009) entitled A 
Socio-Cultural and Linguistic Analysis of Yemeni Arabic Personal Names. This study was an investigation in anthroponomy of a Yemeni community which may reflect the naming practices followed in some tribal regions of Yemen neighboring Saudi Arabia. The study classified the names into different categories. He found that name givers while giving names are influenced by two types of factors: local and external. The local factors include weather names, agricultural names, circumstantial names, weapon names, and clan names. The external factors include the names of continents, countries and cities, foreign names, brands and innovation names. The linguistic analysis of Yemeni personal names shows that the traditional gender distinction marker is more common in the rural areas than in the urban areas because of the limited exposure to the outer world in villages and because of the limited sources people utilize to name their babies.

Ogie (2002) investigates Edo personal names and argues that they are used to affirm certain aspects of Edo culture. The linguistic aspect of the study breaks names into its constituent morphological parts to reveal their meanings.

Based on the aforementioned previous studies, the object of this study is meeting rooms names in the East Java Governmental Building. This study aims to add variations to the same existing studies.

\section{RESEARCH METHOD}

The data in this study are the names of meeting rooms that written on a board of room signs that are installed on each floor in the East Java Governmental Building. This study is a qualitative study that later in its discussion and conclusion, will interpret the data to find out the reasons behind the naming of the meeting rooms in the East Java Governmental Building.

Procedurally, the analysis of the research data was as follows: (1) the researcher writes and takes notes of the names of meeting rooms on each floor in the East Java governmental building; (2) the names of meeting rooms in the East Java governmental building then categorized based on the research objectives (3) from the findings of the data, the researcher then critically analyzed it by providing explanations and discussions which relied on the theoretical arguments they referred to; (4) the next step was to make conclusions based on the existing research findings.

\section{RESULT AND DISCUSSION}

This section deals with the analysis of the names and the interpretation of the results of this analysis. The following are the data which the names are the meeting rooms in the East java Governmental Building.

Table 1. The Names of Meeting Rooms on each floor in the East Java Governmental Building

\begin{tabular}{|c|c|c|c|}
\hline $\begin{array}{l}\text { Level } \\
\text { of the } \\
\text { Buildi } \\
\text { ng }\end{array}$ & $\begin{array}{l}\text { Meeting } \\
\text { Room Name }\end{array}$ & Category & Information \\
\hline $\begin{array}{l}\text { 1st } \\
\text { Floor }\end{array}$ & $\begin{array}{l}\text { Ruang } \\
\text { Airlangga }\end{array}$ & $\begin{array}{l}\text { A King's } \\
\text { Name in } \\
\text { East Java }\end{array}$ & $\begin{array}{l}\text { The only king } \\
\text { of Kahuripan } \\
\text { Kingdom, in } \\
\text { East Java. }\end{array}$ \\
\hline \multirow[t]{2}{*}{$\begin{array}{l}\text { 2nd } \\
\text { Floor }\end{array}$} & $\begin{array}{l}\text { Ruang Rapat } \\
\text { R.T. Soerjo }\end{array}$ & $\begin{array}{l}\text { A } \\
\text { Governor' } \\
\text { s Name in } \\
\text { East Java }\end{array}$ & $\begin{array}{l}\text { The 1st } \\
\text { governor of East } \\
\text { Java, ruled in } \\
1945-1947 \text {. }\end{array}$ \\
\hline & $\begin{array}{l}\text { Ruang Rapat } \\
\text { Dr. Moerdjani }\end{array}$ & $\begin{array}{l}\text { A } \\
\text { Governor' } \\
\text { s Name in } \\
\text { East Java }\end{array}$ & $\begin{array}{l}\text { The } 2 \text { nd } \\
\text { governor of East } \\
\text { Java, ruled in } \\
1947-1949 \text {. }\end{array}$ \\
\hline \multirow[t]{2}{*}{$\begin{array}{l}\text { 3rd } \\
\text { Floor }\end{array}$} & $\begin{array}{l}\text { Ruang Rapat } \\
\text { R. } \\
\text { Samadikoen }\end{array}$ & $\begin{array}{l}\text { A } \\
\text { Governor' } \\
\text { s Name in } \\
\text { East Java }\end{array}$ & $\begin{array}{l}\text { The 3rd } \\
\text { governor of East } \\
\text { Java, ruled in } \\
1949-1957 \text {. }\end{array}$ \\
\hline & $\begin{array}{l}\text { Ruang Rapat } \\
\text { R.T.A. } \\
\text { Milono }\end{array}$ & $\begin{array}{l}\text { A } \\
\text { Governor' } \\
\text { s Name in }\end{array}$ & $\begin{array}{l}\text { The 4th } \\
\text { governor of East } \\
\text { Java, ruled in }\end{array}$ \\
\hline
\end{tabular}




\begin{tabular}{|c|c|c|}
\hline & East Java & 1957-1959. \\
\hline $\begin{array}{l}\text { Ruang Rapat } \\
\text { R. Soewondo } \\
\text { Ranoewdjojo }\end{array}$ & $\begin{array}{l}\text { A } \\
\text { Governor' } \\
\text { s Name in } \\
\text { East Java }\end{array}$ & $\begin{array}{l}\text { The 5th } \\
\text { governor of East } \\
\text { Java, ruled in } \\
1959-1963 \text {. }\end{array}$ \\
\hline $\begin{array}{l}\text { Ruang Rapat } \\
\text { Moch. Wijono }\end{array}$ & $\begin{array}{l}\text { A } \\
\text { Governor' } \\
\text { s Name in } \\
\text { East Java }\end{array}$ & $\begin{array}{l}\text { The 6th } \\
\text { governor of East } \\
\text { Java, ruled in } \\
1963-1967 \text {. }\end{array}$ \\
\hline $\begin{array}{l}\text { Ruang Rapat } \\
\text { R.P. } \\
\text { Mohammad } \\
\text { Noer }\end{array}$ & $\begin{array}{l}\text { A } \\
\text { Governor' } \\
\text { s Name in } \\
\text { East Java }\end{array}$ & $\begin{array}{l}\text { The } 7 \text { th } \\
\text { governor of East } \\
\text { Java, ruled in } \\
1967-1976 \text {. }\end{array}$ \\
\hline $\begin{array}{l}\text { Ruang Rapat } \\
\text { Soenandar } \\
\text { Prijosoedarmo }\end{array}$ & $\begin{array}{l}\text { A } \\
\text { Governor' } \\
\text { s Name in } \\
\text { East Java }\end{array}$ & $\begin{array}{l}\text { The 8th } \\
\text { governor of East } \\
\text { Java, ruled in } \\
1965-1966 \text {. }\end{array}$ \\
\hline $\begin{array}{l}\text { Ruang Rapat } \\
\text { Wahono }\end{array}$ & $\begin{array}{l}\text { A } \\
\text { Governor' } \\
\text { s Name in } \\
\text { East Java }\end{array}$ & $\begin{array}{l}\text { The governor of } \\
\text { East Java, ruled } \\
\text { in } 1983-1988 .\end{array}$ \\
\hline $\begin{array}{l}\text { Ruang Rapat } \\
\text { Soelarso }\end{array}$ & $\begin{array}{l}\text { A } \\
\text { Governor' } \\
\text { s Name in } \\
\text { East Java }\end{array}$ & $\begin{array}{l}\text { The governor of } \\
\text { East Java, ruled } \\
\text { in } 1988-1993 .\end{array}$ \\
\hline $\begin{array}{l}\text { Ruang Rapat } \\
\text { Jayabaya }\end{array}$ & $\begin{array}{l}\text { A King's } \\
\text { Name in } \\
\text { East Java }\end{array}$ & $\begin{array}{l}\text { The King of } \\
\text { Kediri in East } \\
\text { Java from } 1135 \\
\text { to } 1179 \mathrm{CE} \text {. }\end{array}$ \\
\hline $\begin{array}{l}\text { Ruang Rapat } \\
\text { Gajah Mada }\end{array}$ & $\begin{array}{l}\text { A Military } \\
\text { Leader in } \\
\text { Kingdom } \\
\text { in East } \\
\text { Java }\end{array}$ & $\begin{array}{l}\text { A powerful } \\
\text { military leader } \\
\text { or Prime } \\
\text { Minister of the } \\
\text { Majapahit } \\
\text { kingdom, } \\
\text { credited with } \\
\text { bringing the } \\
\text { empire to its } \\
\text { peak of glory. }\end{array}$ \\
\hline $\begin{array}{l}\text { Ruang Rapat } \\
\text { Hayam } \\
\text { Wuruk }\end{array}$ & $\begin{array}{l}\text { A King's } \\
\text { Name in } \\
\text { East Java }\end{array}$ & $\begin{array}{l}\text { A king from } \\
\text { Majapahit } \\
\text { Empire. } \\
\text { Together with } \\
\text { his prime } \\
\text { minister Gajah } \\
\text { Mada, he } \\
\text { reigned the }\end{array}$ \\
\hline
\end{tabular}

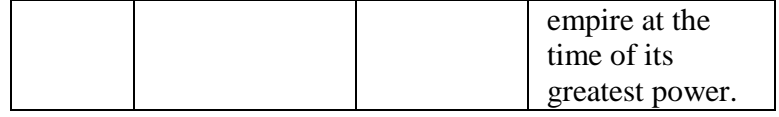

The building of the governmental of East Java was built by the Dutch who colonized Indonesia including East Java. The building was becoming the center administration of the Dutch. Then, in 1945 Indonesia, was announcing its freedom and took over the building to become the governmental building of East Java. The province of East Java was first established in that year (1945) and also became the first year to have its own governor.

Based on the classification of the data, they were classified to two groups: the names of governors in East Java and the names of the kings or military chiefs of great kingdoms in East Java. Meeting room names that are classified to the names of governors in East Java are: second (2nd) floor : - R.T. Soerjo,

- Dr. Moerdjani;

third (3rd) floor $\quad:-$ R. Samadikoen, -R.T.A. Milono;

fourth (4th) floor $\quad:-$ R. Soewondo Ranoewdjojo, Moch. Wijono; fifth (5th) floor: - R.P. Mohammad Noer, -Soenandar Prijosoedarmo; sixth (6th) floor $\quad:-$ Wahono, - Soelarso.

Meeting room names that are classified to the names of kings or military chiefs of great kingdoms in East Java:

first (1st) floor : Airlangga;

seventh (7th) floor : Jayabaya;

7A floor : Gajah Mada;

eighth (8th) floor : Hayam Wuruk.

There are ten meeting rooms that are named after the governor of East Java and four meeting rooms that are classified to the names of kings or 
military chiefs of great kingdoms in East Java in the East Java Governmental Building. These ten rooms are quiet small compared to the four meeting rooms that are named after the names of kings or military chiefs of great kingdom in East Java. These may leads to the fact that those kings or military chiefs have great influence to Indonesia, especially in East Java. Their reign and power were respected by other countries or kingdoms in their era and the core of their kingdoms were in East Java.

While the governors in East Java, not to discredited their services, they only had influence specifically in East Java region. But, the East Java Governmental Buildings still respected their services by naming ten of their meeting rooms in their names, more than the names of the kings or military chiefs.

The researcher assumes that the number of rooms named after the governor of East Java and the names of kings or military chiefs of great kingdoms in East Java in the East Java Governmental Building don't have any big impact in how this region value their ancestors. They all have the same roles, same influence, same effect, and deliver the same message to the people who work or come around this building: to respect and remember their roots and history. The kings or military chief names and the governor names used in this building have a very great value to the next generations and the researcher thinks that there are hopes in these naming so it can last and remembered by the nest generations.

\section{CONCLUSION}

From the results and discussions above, we can see that the East Java Governmental Building tried to preserved East Java history by naming their important rooms with the names of important people who have great influence in their history. As the researcher stated in the introduction of this study, naming is a specific linguistic act, intimately linked with values, traditions, hopes, fears and events in people's lives.

This reflects how this region (East Java) value their ancestors, traditions, and histories. The researcher believed that East Java region tried to plant this value to the next generations therefore they keep respecting their history.

To conclude the research, it can be said that the names of the meeting rooms in the governmental building of East Java are named after important people in the history of the province. After gaining its independence in 1945, the researcher assumes that the administration named all the meeting rooms, as the most important rooms in the building to welcome guests, using the name of people who have big influence and involvement in the history of East Java so that it has roots to its history.

\section{REFERENCES}

Agyekum, K. (2006). The Sociolinguistics of Akan personal names. Nordic Journal of African Studies, 15 (1), 206-235.

Ainiala, Terhi, Minna Saarelma, and Paula Sjoblom. Names in Focus. Helsinki: Studia Fennica Linguistica, 2016.

Alford, R. D. (1987). Naming and identity: A cross-cultural study of personal naming practices. New Haven, Connecticut: HRAF Press.

Al-Zumor, Abdul. "A Socio-Cultural and Linguistic Analysis of Yemeni Arabic Personal." GEMA Online 
Journal of Language Studies, 2009: $15-27$.

Auda, I. D. (2003). Period Arabic names and naming practices. Proceedings of the Known World Heraldic Symposium (pp. 42-56) St. Louis, USA.

Ameliza, Thessa Cynthia; Ambalegin, Ambalegin. (2020) Code Switching Analysis In English Literature Whatsapp Group. Jurnal Basis, [S.L.], V 7, N. 1, P. 141-150, Apr. 2020. Issn 2527-8835. Available At: Http://Ejournal.Upbatam.Ac.Id/I ndex.Php/Basis/Article/View/183 7

Foley, William A. "Anthropological Linguistics." The Encyclopedia of Applied Linguistics, 2012: 1-6.

Koul, O. N. (1995). Personal names in Kashmiri. In Omkar N. Koul (ed.) Sociolinguistics: South Asian perspectives. New Delhi: Creative Books.

Ogie, O. (2002). Edo personal names and world view. In Ohioma I. Pogosan and Francis

O. Egbokhare. (Eds.), New perspectives in Edoid studies: Essays in honour of Ronald Peter Schaefer. Cape Town RSA: Centre for Advanced Studies of African Society, Book Series no. 20

Pamungkas, Kasno, and Rizky Abdulah. "Linguistics-Based Pharmaceutical Product Naming Methods: A Morphological Study on Over the Counter Medicine Products in Indonesia." Asian Journal of Pharmaceutical and Clinical Research, 2017: 108-112.
Prasetyoaji, Anggihat. (2020) Transivity

On Elon Musk's Online

Biography:A Social Actors

Discourse Analysis. Jurnal Basis, [S.L.], V. 7, N. 1, P. 13-24, Apr. 2020. Issn 2527-8835. Available At:

$<$ Http://Ejournal.Upbatam.Ac.Id/ Index.Php/Basis/Article/View/16 73

Rochmawati, Desi. (2020) The Nursing Students Need Of Learning Media For Learning English. Jurnal Basis, [S.L.], V. 7, N. 1, P. 33-46, Apr. 2020. Issn 2527-8835. Available At: $<$ Http://Ejournal.Upbatam.Ac.Id/ Index.Php/Basis/Article/View/18 $\underline{16}$

Rosenhouse, J. (2002). Personal names in Hebrew and Arabic: Modern trends compared to the past. Journal of Semetic Studies, XLVII (1), 97114.

Sharma, D. D. (2005). Panorama of Indian anthroponomy: An historical, socio-cultural and linguistic analysis of Indian personal names. New Delhi: Mittal.

Simanjuntak, Dairi Sapta Rindu.(2015) Penerapan Teori Antropolinguistik Modern (Competence, Performance, Indexicality, \& Partisipation) Dalam Umpasa Budaya Batak Toba. Jurnal Basis, [S.L.], V. 2, N. 2, P. 71-78, Oct. 2015. Issn 2527-8835. Available At: $<$ Http://Ejournal.Upbatam.Ac.Id/ Index.Php/Basis/Article/View/40 7 
Wikipedia. (2020). "Toponymy".

(Online) Retrieved 4 October, 2020 from

https://en.wikipedia.org/wiki/Topon ymy\#: :text=Toponymy\%20or\%20t oponomastics\%20is\%20the, is\%20re ferred $\% 20$ to $\% 20$ as $\% 20$ toponomasti cs

Williams, Carrie. "Research Methods." Journal of Business \& Economic Research, 2007: 65-72. 
